Lublóy Éva ${ }^{1}-$ Gyapjas János ${ }^{2}$

\title{
A betonfelület leválásának hatása a szerkezet állékonyságára és a mentési munkákra
}

\section{The Impact of Detaching Concrete Surface on Construction Sustainability and Saving Works}

\begin{abstract}
A betonfelületek réteges leválása komplexjelenség. Elöregyártott szerkezei elemek, amelyek nagyobb szilárdságú betonból kisebb keresztmetszettel készülnek, érzékenyen reagálnak a hömérséklet emelkedésére. Karcsúbb szerkezetek tervezése során egyre gyakrabban használnak nagy szilárdságú betonokat. A nagy szilárdság lehetővé teszi, hogy karcsúbb szerkezetet tervezzünk, a karcsúbb szerkezet a kisebb keresztmetszete miatt gyorsabban átmelegszik és ezzel egyidejüleg a nagy betonszilárdság miatt fokozottan megnő a betonfelület réteges leválásának az esélye is. A problémát már az MSZ EN 1992-1-2 is tárgyalja, hiszen külön rendelkezik a nagy szilárdságú betonból készült szerkezetekröl, előírja a müanyag szálak alkalmazását a betonfelület robbanásszerü leválásának elkerülése végett. A tüzoltóknak zárt térben is végre kell hajtaniuk a feladataikat. A betonfelület leválása akadályozhatja a mentési feladatok végrehajtását és veszélyeztetheti e beavatkozók testi épségét.
\end{abstract}

Kulcsszavak: betonfelület leválása, betonösszetétel, szerkezeti stabilitás, betonszilárdság hömérsékletfüggése, tüzoltó

Layered release of concrete surfaces is a complex phenomenon. Prefabricated structural pieces made of high-strength concrete with smaller cross sections are sensitive to temperature rise. High-strenth structures are increasingly being used in the design of leaner structures. The high strength makes it possible to design a leaner structure, the leaner structure heats up faster due to

Budapesti Műszaki és Gazdaságtudományi Egyetem, Építőanyagok és Magasépítés Tanszék, docens, e-mail: lubloy.eva@epito.bme.hu, ORCID: https://orcid.org/0000-0001-9628-1318

2 Bács-Kiskun Megyei Katasztrófavédelmi Igazgatóság, igazgatóhelyettes, tű. ezredes, e-mail: janos.gyapjas@ gmail.com, ORCID: https://orcid.org/0000-0001-7088-2123 
its smaller cross-section and, at the same time, increases the likelihood of layering of the concrete surface due to its high concrete strength. The problem is already covered in MSZ EN 1992-1-2, as it has a special regulation for high-strength concrete structures, which requires the use of plastic fibers to avoid explosive separation of the concrete surface. Firefighters must perform their duties indoors. Detaching of the concrete surface may impede rescue tasks and endanger the physical integrity of these interveners.

Keywords: concrete surface separation, concrete composition, structural stability, temperature dependence of concrete strength, firefighter

\section{Tüz hatása a betonra}

\section{Kémiai átalakulások}

A megszilárdult beton adalékanyagból, cementkőből és pórusokból álló, összetett anyag. A hőmérséklet emelkedésének hatására a betonban változások következnek be.

A hőmérséklet emelkedésével megváltozik a beton belső szerkezete és ennek hatására a mechanikai és fizikai tulajdonságai is. Fontos kiemelni, hogy a hőmérséklet emelkedésének hatására a szilárdsági jellemzők romlanak. A beton a lehülés után sem nyeri vissza eredeti tulajdonságait, jellemzőit, mivel a hőterhelés hatására a beton szerkezetében visszafordíthatatlan kémiai és fizikai folyamatok mennek végbe.

A beton tűzterhelés hatására bekövetkező tönkremenetele alapvetően két okra vezethető vissza:

- a beton alkotóelemeinek kémiai átalakulására, illetve

- a betonfelület réteges leválására. ${ }^{3}$

A beton szilárdsági tulajdonságainak változása magas hőmérsékleten függ a cement típusától, az adalékanyag típusától, a víz-cement-tényezőtől, az adalékanyag-cement-tényezőtől, a beton kezdeti nedvességtartalmától és a hőterhelés módjától. ${ }^{4}$

Magas hőmérséklet hatására a beton szerkezete megváltozik. A különböző hőmérsékleti tartományokban a betonban lejátszódó legfontosabb fizikai és kémiai folyamatokat röviden a következőkben foglaljuk össze:

$100{ }^{\circ} \mathrm{C}$ körül a tömegveszteséget a makropórusokból távozó víz okozza. Az ettringit $\left(3 \mathrm{CaOAl} \mathrm{O}_{3} \cdot 3 \mathrm{CaSO}_{4} \cdot 32 \mathrm{H}_{2} \mathrm{O}\right)$ bomlása $50{ }^{\circ} \mathrm{C}$ és $110{ }^{\circ} \mathrm{C}$ között következik be. ${ }^{5} 200{ }^{\circ} \mathrm{C}$ körül további dehidratációs folyamatok zajlanak. A víztartalom (víz-cement-tényező), a cement típusa és a beton kora befolyásolja az eltávozó pórusvíz és a kémiailag kötött víz mennyiségét.

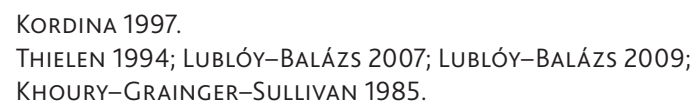


A kiinduló nedvességtartalomtól függő további tömegveszteség $250-300$ C között már nem érzékelhető.

$450{ }^{\circ} \mathrm{C}$ és $550^{\circ} \mathrm{C}$ között a nem karbonátosodott portlandit bomlása következik be $\left(\mathrm{Ca}(\mathrm{OH})_{2} \rightarrow \mathrm{CaO}+\mathrm{H}_{2} \mathrm{O} \uparrow\right)$. Ez a folyamat endoterm (hőelnyelő) csúcsot és ezzel egyidejüleg újabb tömegveszteséget okoz. ${ }^{6}$ A portlandit dehidratációja okozza a legnagyobb szilárdságvesztést a betonban. ${ }^{7}$

Közönséges betonok esetén a kvarc $\alpha$-ból $\beta$ módosulatba való kristály-átalakulása $573^{\circ} \mathrm{C}$-on okoz kis intenzitású endoterm csúcsot. A kvarc átalakulása 5,7\%-os térfogat-növekedéssel jár, ${ }^{8}$ és ez a beton lényeges károsodását eredményezi. $E$ hőmérséklet fölött a beton nem rendelkezik jelentős teherbírással.

$700{ }^{\circ} \mathrm{C}$-on a CSH (kalcium-szilikát-hidrát) vegyületek vízleadással bomlanak, ami szintén térfogat-növekedéssel és további szilárdságcsökkenéssel jár.

A beton kémiai, illetve fizikai szerkezetváltozásának hatására a beton szilárdsági jellemzői is megváltoznak.

\section{Betonfelület leválása}

A betonszerkezetek tüz esetén való tönkremenetelének másik oka a betonfelületek robbanásszerü leválása. A betonfelület réteges leválásának az esélyét a következő tényezők befolyásolják:

- külső tényezők: a tűz jellege, a szerkezetre ható külső terhek nagysága;

- geometriai jellemzők: a szerkezet geometriai adatai, a betonfedés nagysága, a vasbetétek száma és elhelyezkedése;

- a beton összetétele: az adalékanyag mérete és típusa, a cement és a kiegészítő anyag típusa, a pórusok száma, a polipropilén (PP) száladagolás, az acélszál-erősítés, a beton nedvességtartalma, áteresztőképessége és szilárdsága. ${ }^{9}$

Nagy szilárdságú betonok felületének leválását általában a hőmérséklet emelkedésének hatására bekövetkező feszültségek okozzák, míg a szokványos betonok esetében általában a betonból távozó vízgőz feszíti le a felületi rétegeket. Ha a betonfelület egyik oldalát hőterhelés éri, a betonból távozó vízgőz hatására egy vízgőzzel telített réteg alakul ki, ekkor a vízgőz nyomása egyre nő, és végül lefeszíti a betonrétegeket. ${ }^{10} \mathrm{~A}$ betonfelület réteges leválásának esélyét a következő tényezők befolyásolják:

- külső tényezők: a tűz jellege, a szerkezetre ható külső terhek nagysága;

- geometriai jellemzők: a szerkezet geometriai adatai, a betonfedés nagysága, a vasalás acélbetéteinek száma és elhelyezkedése;

\footnotetext{
SCHNEIDER-WEISS 1977.

LUBLÓY-BALÁZS 2007.

WAUBKE 1973.

WINTERBERG-DIETZE 2004.

LUBLÓY-BALÁZS 2009.
} 
- a beton összetétele: az adalékanyag mérete és típusa, a cement és a kiegészítő anyag típusa, a pórusok száma, a polipropilén száladagolás, az acél szálerősítés, a beton nedvességtartalma, áteresztőképessége és szilárdsága. ${ }^{11}$

Minden szerkezet esetében fontos, hogy a betonfelületek réteges leválása tűz esetén lehetőség szerint ne következzen be. Számos kísérlet igazolta, hogy a betonfelület leválásának veszélye mủanyag szálak alkalmazásával jelentősen csökken, mivel a szálváz kiégése során létrejövő pórusszerkezet a szétrepedezés veszélyét csökkenti. ${ }^{12}$

A betonfelület réteges leválását minden esetben el kell kerülni. Ezt leghatékonyabban a megfelelő betonösszetétel megtervezésével és alkalmazásával érhetjük el.

A nagy szilárdságú betonok esetén jóval gyakoribb a betonfelületek leválása, ezért ennek elkerülésére minden esetben ügyelni kell.

A betonfelület leválásának esélyét a következő tényezők befolyásolják:

- nagy szilikapor-tartalom (15 m\% felett),

- nagy nyomószilárdság,

- a nagy tömörség,

- magas relatív nedvességtartalom (80 m\% felett jelentősen nő a veszély),

- adalékanyag típusa (a mészkő adalékanyagú betonok kevésbé hajlamosak a betonfelület leválásra, mint a kvarckavics adalékanyag),

- a vasalás típusa,

- a szerkezeti elem mérete,

- a terhelés intenzitása és típusa. ${ }^{13}$

A betonfelület leválásának elkerülésére a kutatók több lehetőséget vizsgáltak: száladagolás (mủanyag- és acélszálak), cement-kiegészítőanyag adagolása és légbuborékképző adagolása.

\section{Szerkezetek tűzállósága}

\section{Elöregyártott gerendák}

EN 1363-1:2000 számú szabvány szerinti tűzállósági határérték vizsgálata során egyértelműen kiderült, hogy a C40/50 szilárdságú öntömörödő betonból készült gerenda gerincén lévő betonfedés a tüzterhelés 10. percében majdnem teljes egészében levált (1. ábra). A gerenda a teherbíró képességét a tűzvizsgálat 12. percében feltehetően emiatt veszítette el. A betonfelületek lerobbanása a vékony gerinc és a betonösszetétel helytelen megválasztása miatt következett be. ${ }^{14}$

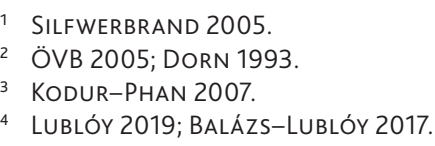




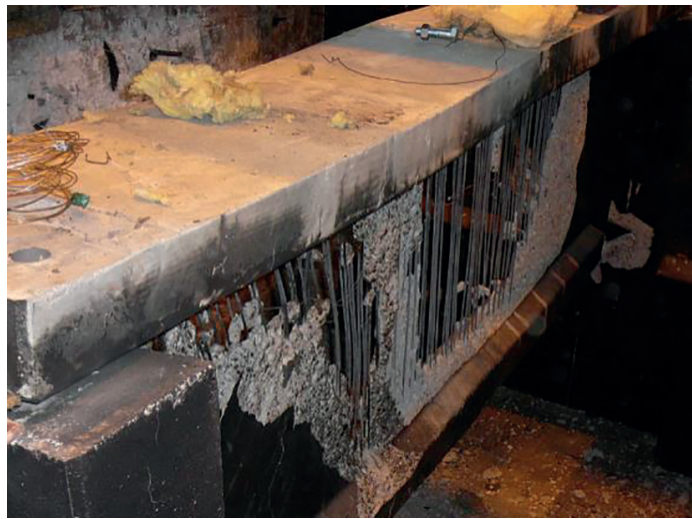

1. ábra. A gerenda

Forrás: BALÁZS-LUBLÓY 2017, 4.

\section{Elöregyártott födémelemek}

EN 1363-1:2000 számú szabvány szerinti tủzálósági határérték vizsgálata során egyértelműen kiderült, hogy a nagy szilárdságú betonból készült elemek esetén a betonfelület leválása miatt a tủzállósági határérték jelentősen csökkenhet TT-panelek esetén (2. ábra).

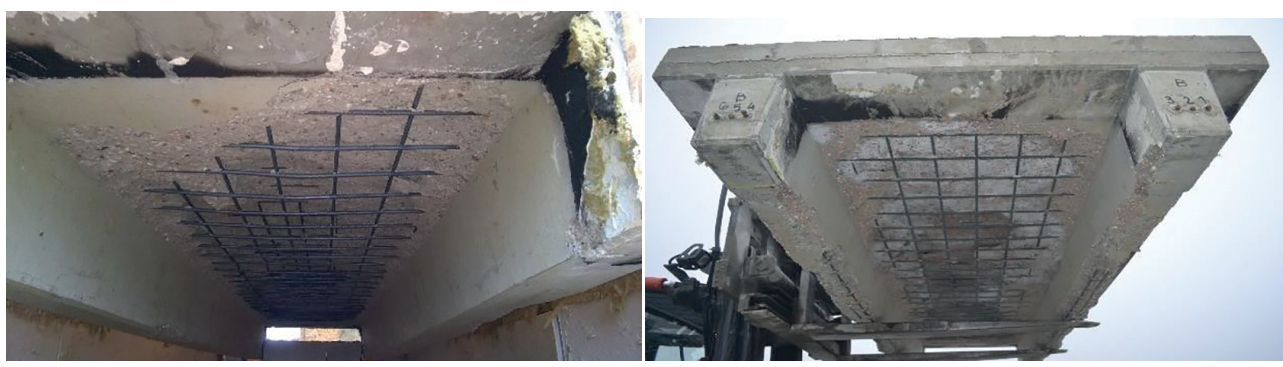

a) az etalon TT-panel a vizsgálat után

b) a módosított TT-panel a vizsgálat után

2. ábra. A TT-panelek a vizsgálat után

Forrás: LUBLóy 2019, 66.

Béléstestekkel készült födémek esetén a béléstestek alsó öve gyakran leválik (3. ábra). A leválás oka a béléstest gerinceinek vékony keresztmetszeti mérete és annak szilárdságcsökkenése miatt a gerinc nem bírja el az alsó öv súlyát és leválik. 


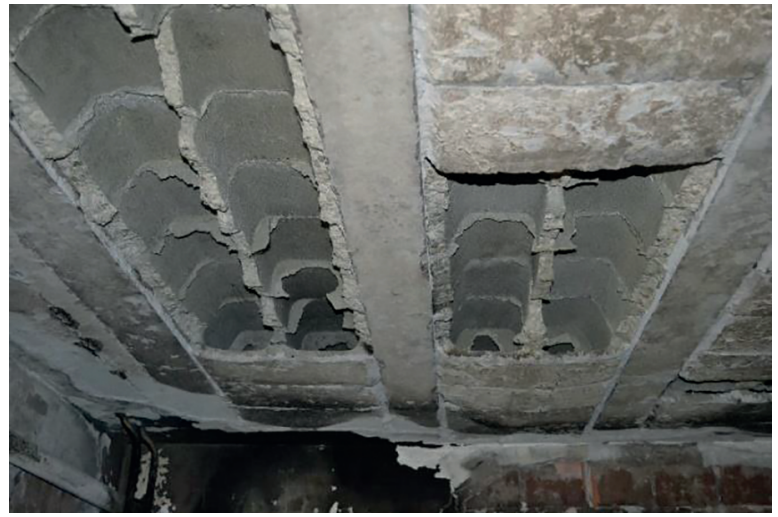

3. ábra. Béléstestek alsó övének leválása

Forrás: BALÁZS-LUBLóY 2017, 5.

\section{Elöregyártott falak}

EN 1363-1:2000 számú szabvány szerinti tüzállósági határérték vizsgálata során a betonfedés a fal majdnem teljes felületén levált, a vizsgálat során már mintegy 5 perc után érzékelhető volt, hogy a betonfelület leválása elkezdödött (4. ábra). A betonfedés leválásnak oka a beton nagy szilárdsága (C 30/37) és az alkalmazott cementtípus (CEM I 52,5 R).

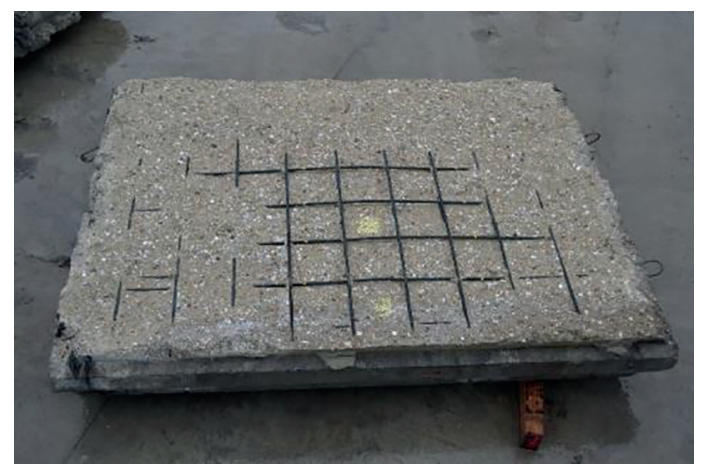

4. ábra. A falpanelelemek károsodása a tűz után

Forrás: LUBLóy 2019, 68. 


\section{A betonfelület leválásának hatása a mentési munkákra}

Magyarországon a tüzoltás állami feladat. ${ }^{15} \mathrm{~A}$ tüzoltási feladatokat alapvetően a 105 hivatásos tűzoltóság hajtja végre, adott esetben az önkormányzati, önkéntes és létesítményi tűzoltóságokkal együttmüködve. $^{16}$

A beavatkozás, tűzoltási feladat legfontosabb eleme az életmentés, része még az anyagi javak védelme, a tűzterjedés megakadályozása, eloltása, és minden egyéb intézkedés a veszély elhárítására. ${ }^{17} \mathrm{~A}$ cél a rendelkezésre álló személyi állománnyal és technikai eszközökkel ennek a lehető leghatékonyabb és legszakszerübb végrehajtása. ${ }^{18} \mathrm{~A}$ beavatkozás részletes szabályait jogszabályok és a BM OKF belső szabályozói tartalmazzák. A legfontosabbak:

- 1996. évi XXXI. törvény a tüz elleni védekezésről, a műszaki mentésről és a tűzoltóságról,

- 39/2011. (XI. 15.) BM rendelet a tűzoltóság tűzoltási és műszaki mentési tevékenységének általános szabályairól,

- 6/2016. (VI. 24.) BM OKF utasítás a Tüzoltás-taktikai Szabályzat és a Műszaki Mentési Szabályzat kiadásáról 1. melléklet, Tüzoltás-taktikai Szabályzat.

A beavatkozó állomány adott esetben épületszerkezetekkel körülvett zárt terekben hajtja végre a feladatait. Bács-Kiskun megyében átlagosan évi 1300 körül van a tüzeseti beavatkozások száma. Az éves adatok alakulását az 5. ábra szemlélteti. Minden tűzesetröl kötelező a statisztikai adatgyűjtés. A zárt térben végzett beavatkozást a statisztikai adatgyűjtés külön nem tartalmazza. A KAP Online (Káreseti Adatgyűjtő Program) segítségével, az adatok elemzése alapján ezt a számot Bács-Kiskun megyében átlagosan 40\%-ra becsülöm.

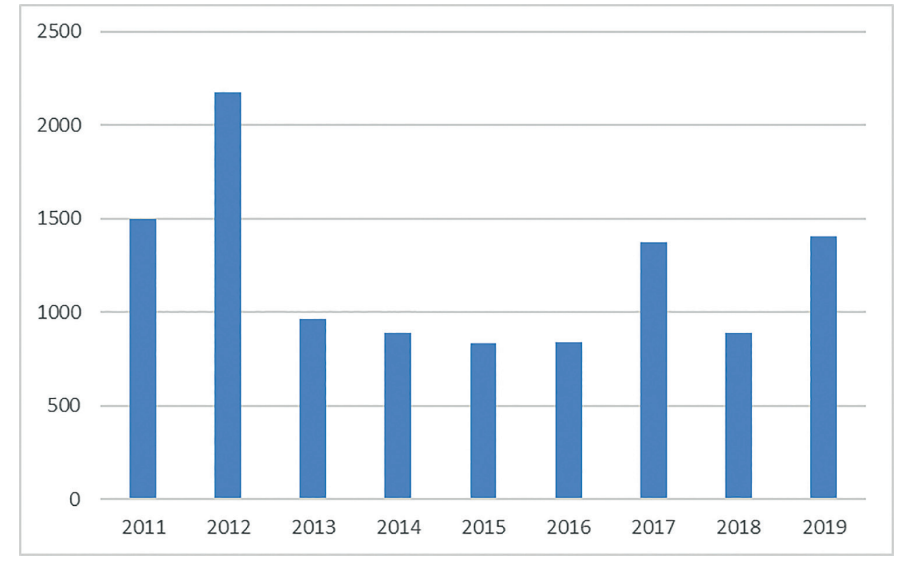

5. ábra. Tüzoltó-beavatkozást igénylő tüzesetek alakulása Bács-Kiskun megyében

Forrás: a szerzők szerkesztése a KAP Online adatbázis adataiból

15 1996. évi XXXI. törvény 2. § (2) bek.

16 www.katasztrofavedelem.hu/212/mento-tuzvedelem (A letöltés dátuma: 2020. 02. 07.)

17 1996. évi XXXI. törvény 4. § e) bek.

18 39/2011. (XI. 15.) BM rendelet 3. § (3) bek. 
A tủzoltó a feladatát - különösen az életmentést - akár élete kockáztatásával is végrehajtja. ${ }^{19}$ A zárt terekben végzett beavatkozás különösen kockázatos. ${ }^{20}$ Ezt jól szemlélteti a 6. ábra.

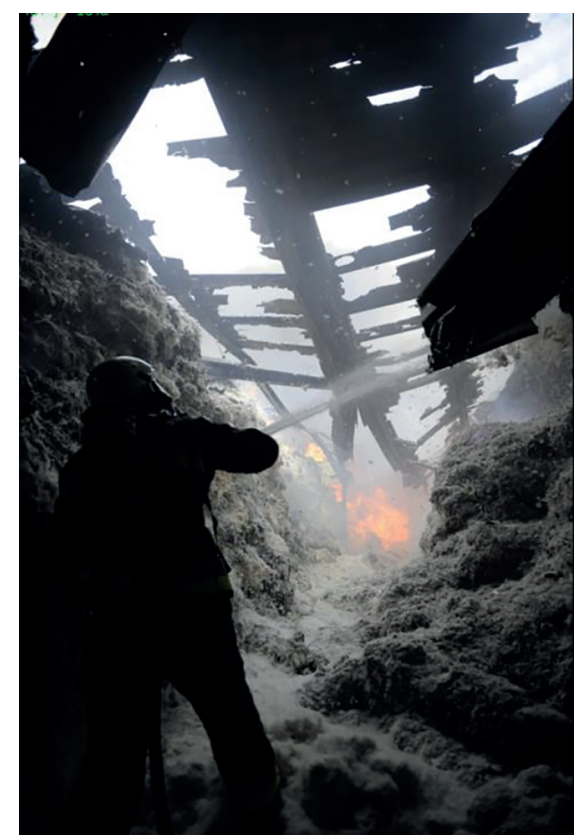

6. ábra. Tüzoltó-beavatkozás és leszakadt tartószerkezet

Pántya adatgyűjtése szerint a beavatkozó tűzoltók sérülései 2000 és 2010 között átlagosan mintegy 2\%-ban (az összes sérülés átlagosan mintegy 290 fő/év volt) származtak lehulló tárgyaktól, omlástól. ${ }^{21}$ Az NFPA statisztikája szerint az Amerikai Egyesült Államokban 2010-2014 között ez átlagosan $11 \%$ volt. ${ }^{22}$ Ezek az adatok is mutatják az épületszerkezetek teljes vagy részleges omlásának veszélyességét. A betonfelület részleges leválása (betondarabok lehullása), illetve ennek hatására a szerkezet tönkremenetele (leomlása) is ebbe a körbe tartozik. Olyan kockázat, ami veszélyezteti a beavatkozó tűzoltót, a mentendő személyt, a beavatkozás eredményes kivitelezését.

19 2015. évi XLII. törvény 44. § (2) bek.

20 PÁNTYA 2017, 48.

21 PÁNTYA 2011, 34.

22 CAMPBELL 2016. 
A tűzoltás egyszemélyi felelős vezetője az úgynevezett tűzoltásvezető. ${ }^{23}$ Restás szerint a gyors és pozitív eredményességü káreseti döntéshozatalt elősegíti a kritikai elemző gondolkodás. ${ }^{24}$ Bérczi doktori értekezésében kiemeli a személyi állomány felkészítésének jelentőségét. ${ }^{25}$ A betonfelületek részleges leválásának kockázatát, a figyelmeztető jeleket ezért indokolt lehet beépíteni a tűzoltók, első körben a tüzoltásvezetésre jogosultak továbbképzésébe.

\section{Összefoglalás}

A betonfelületek réteges leválása komplex jelenség. Az elöregyártott szerkezeti elemek a nagy betonszilárdság és a vékony keresztmetszetek miatt érzékenyen reagálnak a hőmérséklet emelkedésére.

Gerendakísérletek: A gerendakísérlet eredményei alapján megállapíthatjuk, hogy a gerinc betonfedésének leválása a betonösszetételre, valamint a nedvességtartalomra és nem a terhelés mértékére volt visszavezethető. A betonfedés korai leválása a szerkezeti elem tönkremenetelét okozta. Ebben az esetben a gerenda 12 perc után tönkrement, mivel az acélbetétek a betonfedés leválása után gyorsan átmelegedtek, és ezzel egyidejüleg a gerenda elvesztette a teherbírását.

Falvizsgálatok: A falpanelelemeken a betonfedés levált. A betonfedés leválásnak oka a beton nagy szilárdsága és az alkalmazott cementtípus volt.

A jelenség megfelelő tervezési, kivitelezési megoldásokkal megelőzhető, illetve negatív hatása csökkenthető. Azonban az esetleges omlás vagy szerkezet-tönkremenetel veszélyeztetheti a tűzoltási feladat (benne a különösen fontos életmentés) végrehajtását, a beavatkozók testi épségét. Ezt ellensúlyozhatja a kockázat ismerete, időben történő felismerése, ezért javasoljuk a beavatkozó tűzoltó állomány ezirányú továbbképzését.

\section{Köszönetnyilvánítás}

A tanulmány alapjául szolgáló kutatást az Emberi Erőforrások Minisztériuma által meghirdetett Felsőoktatási Intézményi Kiválósági Program, illetve a Bolyai János Ösztöndíj Program támogatta, a BME FIKP-VÍZ tématerületi programja keretében. Az Innovációs és Technológiai Minisztérium ÚNKP-19-4 kódszámú Új Nemzeti Kiválóság Programjának szakmai támogatásával készült.

\section{Felhasznált irodalom}

BALÁZs, György László - LUBLóY, Éva Eszter (2017): Fire resistance for thin-webbed concrete and masonry elements. In BJEGOVIC, W., F. - HOROVA, D. - BURGESS, K. - JELCIC, I. - RUKAVINA, M. eds. Proceedings of the International Conference, Dubrovnik, Prague, Czech Technical University in Prague. 6. DOI: http://dx.doi.org/10.14311/asfe.2015.036

23 39/2011. (XI. 15.) BM rendelet 16. §.

24 RESTÁs 2019, 36.

25 BÉRCZI 2014, 145. 
BÉRCZI László (2014): Az extrém körülmények közötti tüzoltói beavatkozások biztonságát növelö eszközrendszer fejlesztések az integrált katasztrófavédelem rendszerében. Doktori értekezés. Budapest, Nemzeti Közszolgálati Egyetem. DOI: https://doi.org/10.17625/NKE.2014.010

CAMPBELL, Richard (2016): Patterns of Firefighter Fireground Injuries. Research. National Fire Protection Association. Elérhető: www.nfpa.org/-/media/Files/News-and-Research/Fire-statistics-and-reports/Emergency-responders/ospatterns.pdf (A letöltés dátuma: 2020. 02. 07.)

DORN, T. (1993): Berechnung des Tragverhaltens brandbeanspruchter Tragwerke in Verbundbauweise unter besonderer Berücksichtigung der Träger- Stützen Anschlüsse. Heft 99, Braunschweig, Technischen Universität.

Erhöhter baulicher Brandschutz mit Beton für unterirdische Bauwerke (2013). Richtlinie der Österreichischen Bautechnik Vereinigung (ÖBV), August.

Khoury, Gabriel A. - Grainger, Brian N. - Sullivan, Patrick J. E. (1985): Transient thermal strain of concrete: literature review, conditions within specimen and behaviour of individual constituents. Magazine of Concrete Research, Vol 37, No. 132. 131-144. DOI: https://doi.org/10.1680/ macr.1985.37.132.131

KODUR, V.K.R. - PHAN, L. (2007): Critical factors governing the fire performance of high strength concrete systems. Fire Safety Journal, Vol. 42, No. 6-7. 482-488. DOI: https://doi.org/10.1016/j. firesaf.2006.10.006

KORDINA, Karl (1997): Über das Brandverhalten punktgestützter Stahlbetonbalken. Berlin, Beuth Verlag $\mathrm{GmbH}$.

KovÁcs Andrea (2018): Tüzoltó beavatkozás és leszakadt tartószerkezet. Fénykép. Kecskemét, Bács-Kiskun Megyei Katasztrófavédelmi Igazgatóság archívuma.

LUBLóy, Éva - BALÁzs, László György (2007): Modifications of material properties due to elevated temperatures. Advances in Construction Materials, Heidelberg, Springer. 307-314. DOI: https:// doi.org/10.1007/978-3-540-72448-3_31

LUBLóY Éva - BALÁzs László György (2009): Magas hőmérséklet hatása a vasbeton szerkezetek anyagaira. Vasbetonépités, 2. sz. 48-54.

LUBLÓY Éva Eszter (2019): Hogyan befolyásolja a betonszilárdság a tüzállósági határértéket? Védelem Tudomány, 4. sz. 50-73.

PÁNTYA Péter (2011): Zárt térben történő tüzoltói beavatkozások kockázatának csökkentése. Doktori értekezés. Budapest, Zrínyi Miklós Nemzetvédelmi Egyetem.

PÁNTYA Péter (2017): Füsttel telített, zárt terekben történő tűzoltói beavatkozások vizsgálata a biztonság szempontjából. Bolyai Szemle, Ksz. 47-58.

RESTÁs Ágoston (2019): A kényszerhelyzeti döntések sajátosságai a tüzoltás során. Védelem Tudomány, 4. évf. 3. sz. 27-39.

SCHNEIDER, U. - WEISS, R. (1977): Kinetische Betrachtungen über den thermischen Abbau zementgebundener Betone und dessen mechanische Auswirkungen. Cement and Concrete Research, Vol 7, No. 3. 259-267. DOI: https://doi.org/10.1016/0008-8846(77)90087-4

SILFWERBRAND, Johan (2005): Guidelines for preventing explosive spalling in concrete structures exposed to fire. In BALÁzs, László György - BOROSNYóı, Adorján szerk: Proceedings of Keep Concrete Attractive symposium, Hungarian Group of fib. Budapest, 23-25 Mai 2005, Budapest, Budapest University of Technology and Economics. 1148-1156.

THIELEN, KC (1994): Strength and Deformation of Concrete Subjected to high Temperature and Biaxial Stress-Test and Modeling (Festigkeit und Verformung von Beton bei hoher Temperatur und biaxialer Beanspruchung Versuche und Modellbildung). Berlin, Beuth Verlag $\mathrm{GmbH}$.

WAUBKE, N. V. (1973): Über einen physikalischen Gesichtspunkt der Festigkeitsverluste von Portlandzementbetonen bei Temperaturen bis $1000^{\circ} \mathrm{C}$ Brandverhalten von Bauteilen. Doktori értekezés. TU Braunschweig.

WINTERBERG, Ralf - DIETZE, Richard (2004): Efficient passive fire protection systems for high performance shotcrete. In BERNARD, Erik Stefan szerk.: Proceeding for the Second International Conference on Engineering Developments in Shotcrete, Cairns, Australia, October 2004. Leiden, CRC Press. 271-291. 


\section{Jogi források}

1996. évi XXXI. törvény a tűz elleni védekezésről, a műszaki mentésről és a tűzoltóságról

2015. évi XLII. törvény a rendvédelmi feladatokat ellátó szervek hivatásos állományának szolgálati jogviszonyáról

39/2011. (XI. 15.) BM rendelet a tűzoltóság tűzoltási és műszaki mentési tevékenységének általános szabályairól

\section{Internetes forrás}

Mentő tüzvédelem. Elérhető: www.katasztrofavedelem.hu/212/mento-tuzvedelem (A letöltés dátuma: 2020. 02. 07.) 